EESTI NSV TEADUSTE AKADEEMIA TOIMETISED 1955, IV kd., nr. 4 ИЗВЕСТИЯ АКАДЕМИИ НАУК ЭСТОНСКОИ ССР 1955. Том IV, № 4

\title{
КАТАЛИТИЧЕСКИЙ МЕТОД ПЕРЕРАБОТКИ СЛАНЦЕВОЙ СМОЛЫ
}

\author{
А. т. Кылль, \\ кандидат химических наук \\ С. И. ФАЙГОЛьд, \\ кандидат технических наук
}

M. Ю. КОРВ

В предыдущих работах лаборатории переработки сланцевых продуктов $\left({ }^{2},{ }^{10}\right)$ была показана перспективность развития исследовательских работ по каталитической переработке бензиновых фракций сланцевой смолы в присутствии хлористого цинка. Хлористый цинк является более слабым катализатором, чем хлористый алюминий. Это позволяет при полимеризации избежать алкилирования ароматических углеводородов и сохранить в бензине стабильные олефиновые углеводороды. С. С. Семенов и Б. Гуревич $\left({ }^{4}\right)$, проведя полимеризацию сланцевого бензина в присутствии хлористого алюминия, получили бензин, содержащий $98 \%$ парафиновых и нафтеновых углеводородов; следовательно, все ароматические соединения были выведены из бензина алкилированием и полимеризацией. А. В. Топчиев, М. В. Курашев и Б. А. Кренцель $\left({ }^{9}\right)$ указывают, что алкилирование ароматических углеводородов в присутствии хлористого алюминия проходит уже при температурах $20-50^{\circ}$.

При полимеризации дизельной фракции сланцевой смолы условия несколько изменяются. Ароматические соединения не являются ценными компонентами дизельных топлив и должны быть по возможности удалены. Выход сырой масляной фракции при применении хлористого алюминия больший, чем при применении хлористого цинка. В присутствии хло́ристого алюминия из дизельной фракции нами получен выход смазочных масел до $50 \%$ от исходной фракции, в то время как при применении хлористого цинка выход их составлял не более $35 \%$. Тем не менее и при переработке дизельной фракции хлористый цинк имеет ряд преимуществ, отсутствующих у хлористого алюминия. Химический состав непредельных соединений сланцевой смолы свидетельствует о том, что наряду с возможностью получения при полимеризации качественных смазочных масел должно иметь место образование конденсированных систем, обладающих высокими коксовыми числами и недостаточной окислительной стабильностью при высоких температурах. Қаталитические свойства хлористого цинка позволяют в первой стадии процесса провести полимеризацию наиболее реакционноспособных соединений и получить индустриальные масла, к которым не предъявляются высокие требования по коксуемости. При этом в широкой дизельной фракции остается большинство олефинов, 
являющихся ценным исходным сырьем для получения качественных смазочных масел.

Во второй стадии процесса для увеличения выхода масел может быть добавлен хлористый алюминий, однако при этом следует в каждом отдельном случае подобрать количества его и условия во избежание чрезмерного комплексообразования. В этой стадии процесса возможно осуществление в определенных пределах алкилирования ароматических углеводородов, так как алкилароматические соединения с длинной парафиновой цепью обладают низкой температурой застывания и являются желательными компонентами смазочных масел $\left({ }^{1}\right)$.

\section{Исходное сырье}

В качестве исходного сырья нами была выбрана промышленная фракция смолы туннельных печей - легкое масло. Целесообразность такого выбора объясняется: 1) широким фракционным составом продукта, обеспечивающим одновременное получение бензина, дизельного топлива и смазочных масел с хорошими выходами товарных продуктов; 2) малой себестоимостью этого масла и возможностью более полно использовать фенолы легкого масла; 3) относительно невысоким парциальным давлением паров при температурах полимеризации, что позволяет упростить аппаратурное оформление процесса и при атмосферном давлении устранить потери продукта от испарения.

Физико-химические показатели исходных проб легкого масла туннельных печей приведены в таблице 1. Первая проба легкого масла после де-

Характеристика исходных проб

таблица 1

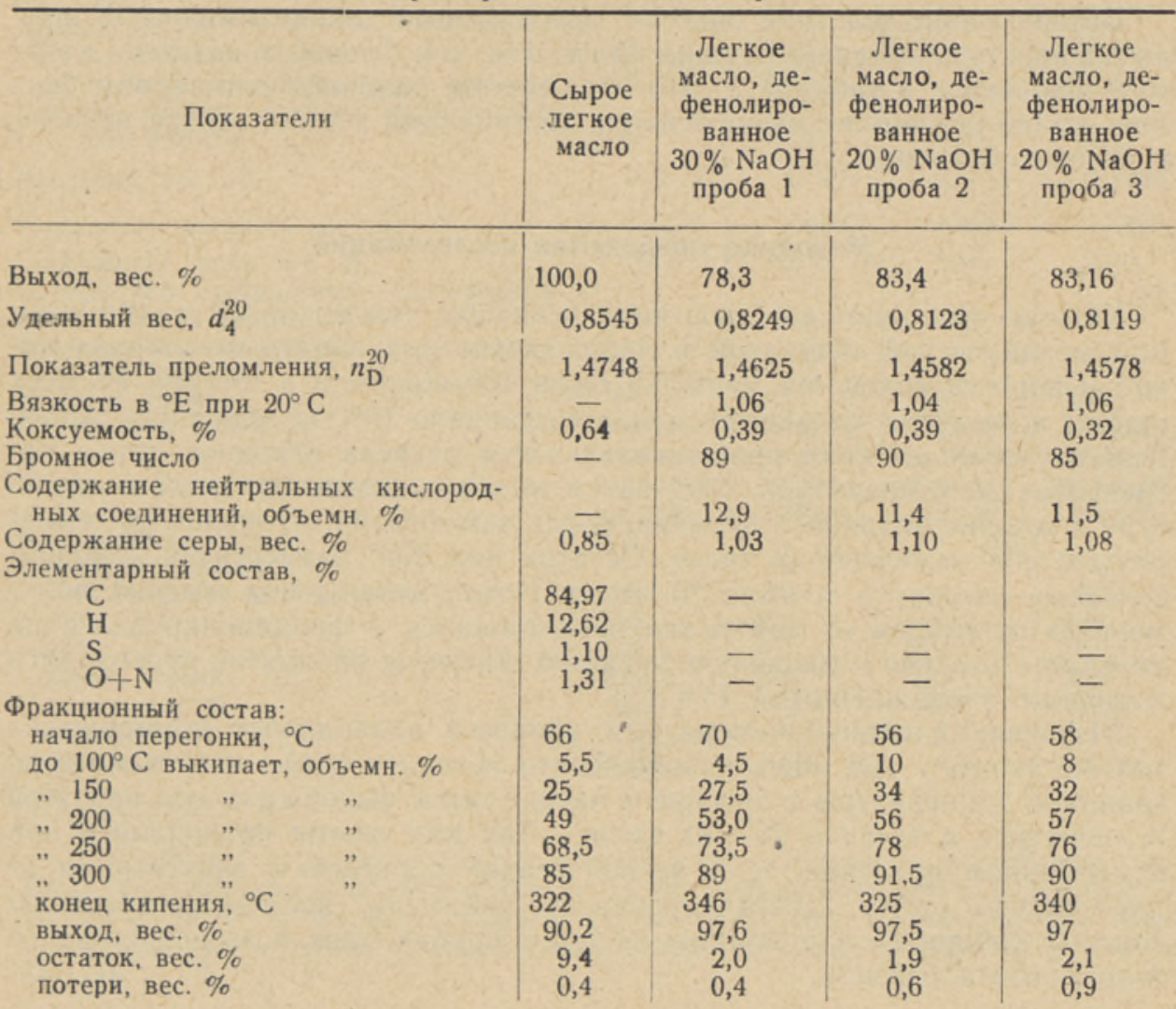


фенолирования была фракционирована на две фракции: - выкипающую до $205^{\circ}$ и остаток. Бензиновая фракция очищена серной кислотой по методике, принятой в промышленности.

Характеристика сырого и очищенного серной кислотой бензинов, а также остатка выше $205^{\circ}$ приведена в таблице 2.

Таблица 2

Показатели продуктов, полученных из легкого масла фракционированием и сернокислотной очисткой

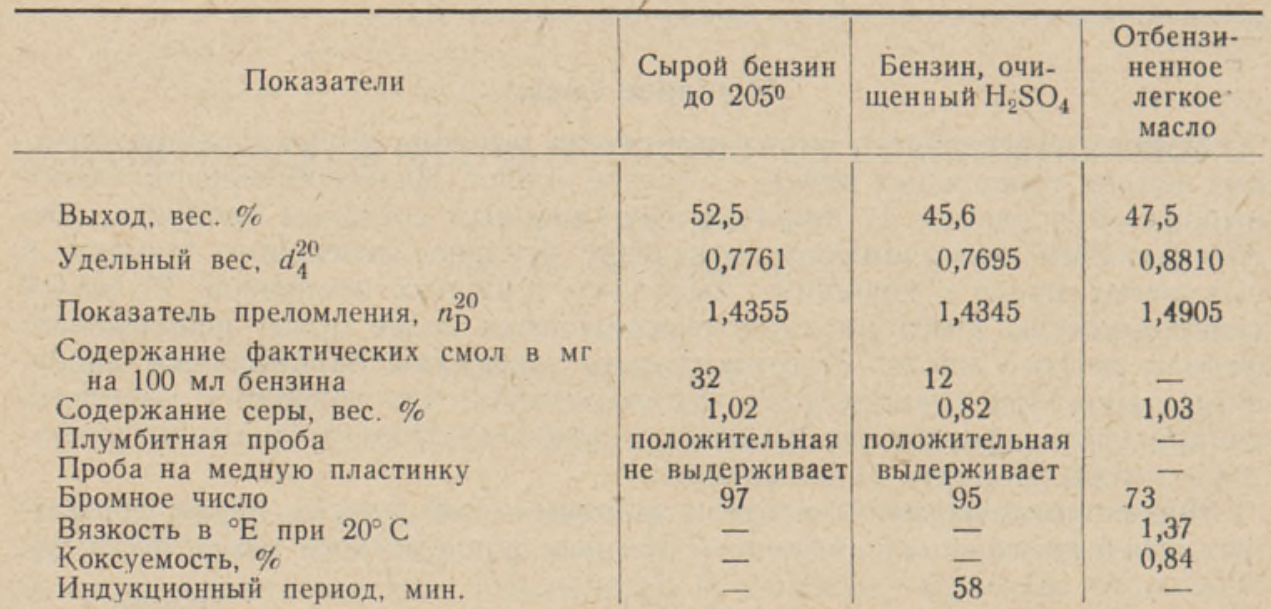

Бензин сернокислотной очистки, выпускаемый сланцехимической промышленностью, обладает лучшим качеством, чем бензин, показатели которого приведены в таблице 2. Это объясняется наличием в товарном бензине, кроме указанного выше бензина дестилляции легкого масла, печного и газового бензина.

\section{Методика проведения исследований}

Опыты проводились в железном реакторе, емкостью 4,5 л, снабженном механической мешалкой и либиховским или обратным холодильником. Скорость вращения мешалки была 100 оборотов в минуту. Во всех опытах количество хлористого цинка составляло $10 \%$ от исходного сырья. При изучении влияния продолжительности нагрева исходное сырье нагревалось до температуры $100^{\circ}$, затем выдерживалось при этой температуре в течение заданного времени, после чего бензин отгонялся до температуры $205^{\circ}$ в течение 2 часов. Остаток при $200^{\circ}$ подвергался дополнительному нагреву в течение 20 часов. После охлаждения жидкий полимеризат отделялся от комплекса, фильтровался и фракционировался на дизельное топливо и масляную фракцию. Анализы продуктов проводились методами, утвержденными ГОСТ.

Изучение влияния температуры процесса проводилось примерно по той же схеме, с той лишь разницей, что исходное сырье нагревалось до заданной температуры в течение 2 часов, затем выдерживалось при этой температуре в течение 25-30 часов. Так как опыты проводились при атмосферном давлении, то в первой стадии процесса, в зависимости от температуры опыта, дестиллировалось некоторое количество бензина, который собирался в приемнике и затем прибавлялся к выделенному из полимеризата бензину. 
В предыдущих работах $(2,10)$ нами было показано, что смазочные масла с малой коксуемостью можно получить путем вакуумной дестилляции широкой масляной фракции. В данной работе мы стремились получить вначале лишь сравнительные результаты и изучить возможности получения качественных смазочных масел, не прибегая к глубокой вакуумной дестилляции. В результате изучения влияния продолжительности нагрева и температуры процесса была намечена общая схема переработки легкого масла туннельных печей. По этой схеме проведены дублированные опыты, на основании которых в заключительном разделе настоящей статьи приведены данные материального баланеа и данные о качестве товарных продуктов.

\section{Влияние продолжительности нагрева}

Влияние продолжительности нагрева при низких температурах $(80$ $100^{\circ}$ ) было нами освещено в предыдущей работе $\left({ }^{2}\right)$. Это влияние резче выражается при более высоких температурах процесса полимеризации. В таблице 3 приведены физико-химические показатели бензинов, полученных при различной продолжительности нагрева.

Таблица 3

Влияние продолжительности нагрева на качество бензина

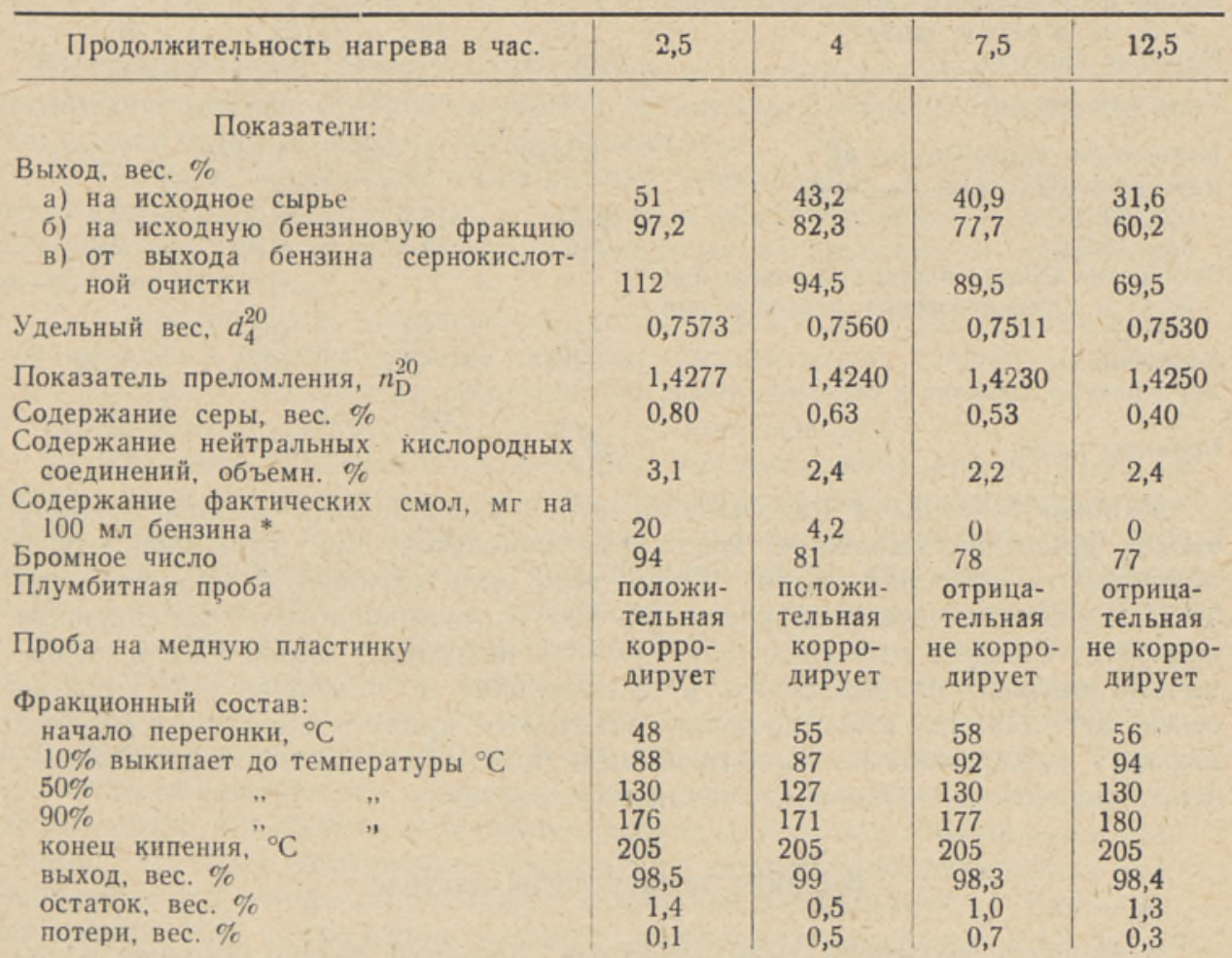

* В опыте с продолжительностью нагрева 4 часа содержание фактических смол после месячного хранения увеличилось до 6,8 мг, а после двухмесячного хранения до 12,4 мг на 100 мл бензнна. В опыте с продолжительностью нагрева 12,5 часа после восьмимесячного хранення содержание фактических смол составило 5,6 мг на 100 мл бензина. 
С увеличением продолжительности нагрева качество бензина улучшается за счет меньшего выхода его. Улучшение качества бензина вначале осуществляется за счет удаления диолефинов, наиболее реакционноспособной части моноолефинов, нейтральных кислородных соединений и азотистых оснований. Сернистые соединения удаляются труднее. В данных условиях уже после четырехчасового нагрева бензин становится бесцветным и стабильным, хотя содержание серы в нем составляет $0,63 \%$. При дальнейшем увеличении продолжительности нагрева содержание серы в бензине может быть доведено до $0,15 \%$.

В результате изменения выходов и качества бензина в зависимости от продолжительности нагрева изменяются выход и качество фракции смазочных масел.

В таблице 4 представлены данные о влиянии продолжительности нагрева и количества отобранного бензина на выход и качество фракции смазочного масла.

Таблица 4

Влияние количества отобранного бензина на качество смазочного масла

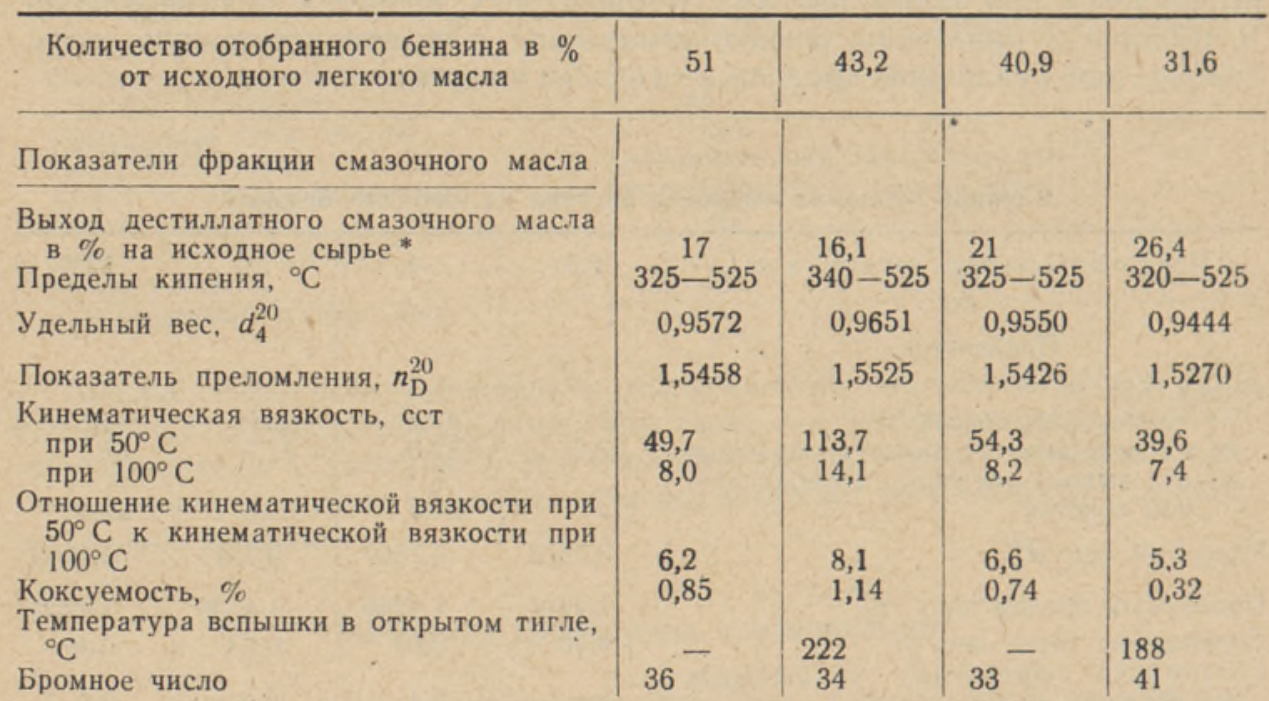

Данные таблицы 4 показывают, что с уменьшением отбора бензина выход фракции смазочного масла увеличивается, при этом вязкость и коксуемость его снижаются. Отношение кинематической вязкости при $50^{\circ} \mathrm{C}$ к кинематической вязкости при $100^{\circ} \mathrm{C}$ увеличивается с увеличением вязкости. Следует отметить, что $10-15 \%$ исходного масла уже в самом начале нагрева превращается в полимеризат с температурой кипения выше $350^{\circ}$. Наряду с большой вязкостью этот продукт обладает наиболее высокой коксуемостью. В дальнейшем полимеризация протекает медленее, но качество смазочного масла улучшается.

\section{Влияние температуры нагрева}

В процессе полимеризации олефинов сланцевой смолы большое влияние оказывает температура нагрева. Так Ч. Томас $\left({ }^{8}\right)$ приводит данные о том, что олефины изостроения полимеризуются в присутствии солей галоидных металлов уже при $-10^{\circ}$. С изменением температуры изме-

* В опыте, где было отобрано $43,2 \%$ бензина, выход фракции смазочного масла, выкипающего в интервале $320-525^{\circ}$, составил $20,8 \%$. 
няется и направление химических реакций. Один и тот же олефин, в зависимости от температурного режима, может при полимеризации превратиться в термостабильный полимер нормального строения или образовать циклические системы, отрицательно влияющие на качество смазочных масел. В данном исследовании процесс полимеризации изучался в пределах температур $100-200^{\circ}$, так как в присутствии хлористого цинка процесс при температурах ниже $100^{\circ}$ настолько земедляется, что становится технически нецелесообразным, а выше $200^{\circ}$ начинают заметно проявляться реакщии крекинга.

Нами были проведены опыты при одинаковых примерно продолжительности нагрева и составе исходного сырья и при температурах нагрева $100,125,140,150$ и $200^{\circ}$. Сравнительные данные о выходах отдельных продуктов представлены в таблице 5 .

Таблица 5

Выходы продуктов полимеризации при различной температуре процесса

\begin{tabular}{l|l|l|l|l|l}
\hline Температура ${ }^{\circ} \mathrm{C}$ & 100 & 125 & 140 & 150 & 200 \\
\hline Продукт & & & & \\
Бензин & 31,2 & 22,5 & 22,9 & 25,2 & 31,6 \\
Дизельное топливо & 35,4 & 37,1 & 32,2 & 32,2 & 27,5 \\
Смазочные масла & 17,6 & 26,0 & 30,1 & 31,9 & 29,4 \\
Органическая часть комплекса & 15,8 & 14,4 & 14,8 & 10,7 & 11,5
\end{tabular}

C повышением температуры процесса полимеризации количество сырья, связывающееся в комплекс с хлористым цинком, уменьшается. Это может быть объяснено двумя причинами.

1. По мере повышения температуры уменьшается количество бензиновых фракций, участвующих в процессах полимеризации и комплексообразования, так как эти фракции выводятся из реактора по мере повышения температуры.

2. С увеличением температуры уменьшается стабильность комплекса. Увеличивается дегидрирующее действие катализатора. Часть сернистых и кислородных соединений разлагается.

Более заметно влияет, повидимому, вторая причина.

Параллельно с выводом из реакционной зоны бензиновых фракций должна была бы увеличиться степень полимеризации и комплексообразования оставшихся в реакторе более высококипящих фракций. Это привело бы к увеличению выхода орғанической части комплекса. Однако опыты показали, что этого не происходит. С повышением температуры процесса и уменьшением количества органической части комплекса изменяется качество последнего. Комплекс, полученный при температуре $100^{\circ}$, легко разрушается водой. В результате катализатор переходит в раствор, увлекая с собой некоторую часть кислородных соединений, а основная часть органического вещества комплекса выделяется в виде маслянистого слоя, который в дальнейшем может найти себе специальное применение. По мере увеличения температуры процесса подвижность и растворимость в бензоле получаемого комплекса уменьшаются. Комплекс, полученный при температуре процесса полимеризации выше $150^{\circ}$, водой не разрушается. При нагревании его происходит разложение, сопровождающееся выделением газов, обладающих резким запахом. Таким образом, опыты показали, что легко регенерировать катализатор и использовать квалифицированно органическую часть комплекса можно только при условии, если температура процесса полимеризации не превышает $150^{\circ}$. Чем ниже температура процесса, тем легче регенерируется катализатор. 
В таблице 6 приведены данные по качеству суммарного полимеризата, полученного при различной температуре процесса. Эти данные показывают, что с возрастанием температуры процесса степень полимеризации увеличивается.

Таблица 6

Влияние температуры на качество суммарного полимеризата

\begin{tabular}{l|c|c|c|c}
\hline Температура в ${ }^{\circ} \mathrm{C}$ & 100 & 125 & 140 & 150 \\
Показатели & & & & \\
\hline Выход на исходное сырье, вес. \% & 84,2 & 85,6 & 85,2 & 89,3 \\
Удельный вес, $d_{4}^{20}$ & 0,8371 & 0,8549 & 0,8521 & 0,8480 \\
Показатель преломления, $n_{\mathrm{D}}^{20}$ & 1,4684 & 1,4784 & 1,4776 & 1,4770 \\
Вязкость при 20․ в сст & 2,92 & 4,93 & 5,12 & 3,90 \\
Бромное число & 69 & 47 & 33 & 38 \\
Коксуемость, \% & 0,45 & 0,37 & 0,37 & 0,41 \\
Содержание серы, вес. \% & 0,84 & 0,80 & 0,72 & 0,76 \\
Продолжительность полимеризацин, & 35 & 25 & 35 & 25 \\
час. &
\end{tabular}

Данные таблицы 6 свидетельствуют, что с увеличением температуры, при прочих равных условиях, выход бензина уменьшается; при этом следует учесть, что в опытах с температурой нагрева 150 и $200^{\circ}$ производился отбор фракций бензина по мере повышения температуры. Физико-химические показатели бензинов, полученных при различной температуре процесса, приведены в таблице 7.

Таблица 7

Характеристика бензинов, полученных при различных температурах процесса

\begin{tabular}{|c|c|c|c|c|c|}
\hline $\begin{array}{ll}\text { Пемпература } & \text { в }{ }^{\circ} \mathrm{C} \\
\text { Показатели } & \end{array}$ & 100 & 125 & 140 & 150 & 200 \\
\hline 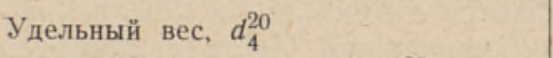 & 0,7556 & 0,7392 & 0,7341 & 0,7406 & 0,7530 \\
\hline Показатель преломления, $n_{\mathrm{D}}^{20}$ & 1,4253 & 1,4180 & 1,4150 & 1,4178 & 1,4250 \\
\hline $\begin{array}{l}\text { Содержание серы, вес. \% } \\
\text { Содержание нейтральных кислород- }\end{array}$ & 0,32 & 0,21 & 0,17 & 0,18 & 0,4 \\
\hline $\begin{array}{l}\text { ных соединений, объемн. \% } \\
\text { Содержание фактических смол в мг }\end{array}$ & 1,0 & 0,8 & - & 0,6 & 2,5 \\
\hline & & $\begin{array}{r}0 \\
40\end{array}$ & & $\begin{array}{r}0 \\
38\end{array}$ & $\begin{array}{r}0 \\
77\end{array}$ \\
\hline $\begin{array}{l}\text { Плумбитная проба } \\
\text { Проба на медную пластинку }\end{array}$ & $\begin{array}{l}\text { отрица- } \\
\text { тельная } \\
\text { выдер- } \\
\text { живает }\end{array}$ & $\begin{array}{l}\text { отрица- } \\
\text { тельная } \\
\text { выдер-- } \\
\text { живает }\end{array}$ & $\begin{array}{c}\text { отрица- } \\
\text { тельная } \\
\text { выдер- } \\
\text { живает }\end{array}$ & $\begin{array}{l}\text { отрица- } \\
\text { тельная } \\
\text { выдер- } \\
\text { живает }\end{array}$ & $\begin{array}{l}\text { отрица- } \\
\text { тельная } \\
\text { выдер- } \\
\text { живает }\end{array}$ \\
\hline $\begin{array}{l}\text { Индукционный период, мин. } \\
\text { Содержание потенциальных смол в } \\
\text { мг на } 100 \text { мл бензина } \\
\text { Фракционный состав: }\end{array}$ & $\begin{array}{c}\text { выше } 355 \\
12\end{array}$ & - & $\begin{array}{c}\text { выше } 355 \\
10\end{array}$ & - & - \\
\hline $\begin{array}{l}\text { начало перегонки, }{ }^{\circ} \mathrm{C} \\
10 \% \text { перегоняется при температуре, } \\
50 \% \text { перегоняется при температуре, } \\
90 \% \text { перегоняется при температуре, } \\
\text { конец кипения, }{ }^{\circ} \mathrm{C} \\
\text { выход, вес. \% } \\
\text { остаток, вес. \% } \\
\text { потери вес. \% }\end{array}$ & $\begin{array}{r}62 \\
90 \\
127 \\
186 \\
205 \\
95,9 \\
2,9 \\
1,2\end{array}$ & $\begin{array}{r}48 \\
80 \\
131 \\
192 \\
205 \\
97,9 \\
1,4 \\
0,7\end{array}$ & $\begin{array}{r}46 \\
74 \\
130 \\
190 \\
205 \\
98,2 \\
1,3 \\
0,5\end{array}$ & $\begin{array}{r}50 \\
82 \\
131 \\
190 \\
205 \\
98,2 \\
1,4 \\
0,4\end{array}$ & $\begin{array}{r}56 \\
94 \\
130 \\
180 \\
205 \\
98,4 \\
1,2 \\
0,4\end{array}$ \\
\hline
\end{tabular}

* В тех опытах, где фактические смолы в свежеприготовленном бензине отсутствовали, содержание их после восьмимесячного хранения составнло 6 мг на 100 мл бензина. 
Содержание серы в бензине снижается по мере увеличения температуры процесса до $140-150^{\circ}$, а после этого содержание серы начинает увеличиваться. Это, повидимому, объясняется разложением сернистых соединений, связанных с комплексом. Следует отметить, что влияние температуры в этом отношении может быть компенсировано увеличением продолжительности нагрева.

Весьма важным показателем, характеризующим влияние температуры нагрева, является содержание в бензине непредельных углеводородов. Абсолютное содержание олефинов в очищенном бензине не всегда однозначно связано с его качеством. С увеличением температуры нагрева ненасыщенность бензина уменьшается, о чем свидетельствуют значения бромного числа; при этом нужно учесть, что в опытах при температурах 150 и $200^{\circ}$ производился отбор фракций бензина по мере повышения температуры. При более низких температурах процесса олефины удаляются медленнее, но бензин все же получается хорошего качества. Утверждения И. А. Уска и И. Г. Столера $\left(^{5}\right)$ о нехарактерности индукционного периода как показателя стабильности сланцевых бензинов для данного случая очистки являются неверными. Очищенный жидкофазной полимеризацией бензин, несмотря на наличие в нем более $50 \%$ олефиновых углеведородов, обладает индукционным периодом более 355 мин., и содержание в нем потенциальных смол не превышает 12 мг на 100 мл бензина. Это свидетельствует о том, что при соответствующих условиях очистки сланцевый бензин не уступает по качеству стабильным нефтяным бензинам.

Выход фракции дизельного топлива с увеличением температуры нагрева уменьшается. В таблице 8 представлены техно-химические показатели фракций дизельного топлива, отобранных в интервале температур $200-320^{\circ}$, в опытах с различной температурой нагрева.

Данные таблицы 8 показывают, что качество дизельного топлива улучшается с повышением температуры нагрева. Уменьшается содержание серы и нейтральных кислородных соединений, а главное, значительно увеличивается стабильность топлива. С повышением температуры процесса во фракциях дизельного топлива резко сокращается содержание непредельных углеводородов. Дизельные фракции, полученные при температурах опыта $100-125^{\circ}$, являются хорошим сырьем для дальнейшей полимеризации на смазочные масла. В них отсутствуют диолефины, большая часть нейтральных кислородных соединений и некоторые моноолефины изостроения, обладающие высокой реакционной способностью. Высокие значения бромных чисел этих дизельных фракций позволяют обеспечить значительный выход качественных смазочных масел,

В таблице 9 приведены данные по качеству масляных фракций, полученных в опытах в различной температурой нагрева.

Приведенные данные показывают, что в зависимости от температуры. нагрева можно получить различный выход масляной фракции, но получить только изменением температурных условий качественное масло, обладающее хорошими моторными свойствами, не удается.

Нами было проведено изучение (в аппарате Папока) моторных свойств более 30 проб сланцевых смазочных масел. Масла были получены из смол различных технологических установок переработки сланца при различных температурах и продолжительности опыта и с различными катализаторами (хлористый цинк и хлористый алюминий). Все остаточные масла имели неудовлетворительное содержание рабочей фракции. Содержание рабочей фракции в остаточном масле возрастает с увеличением температуры кипения фракции. Для сланцевых масел одноступенчатой полимеризации в присутствии $\mathrm{ZnCl}_{2}$ порядок значений величин, 


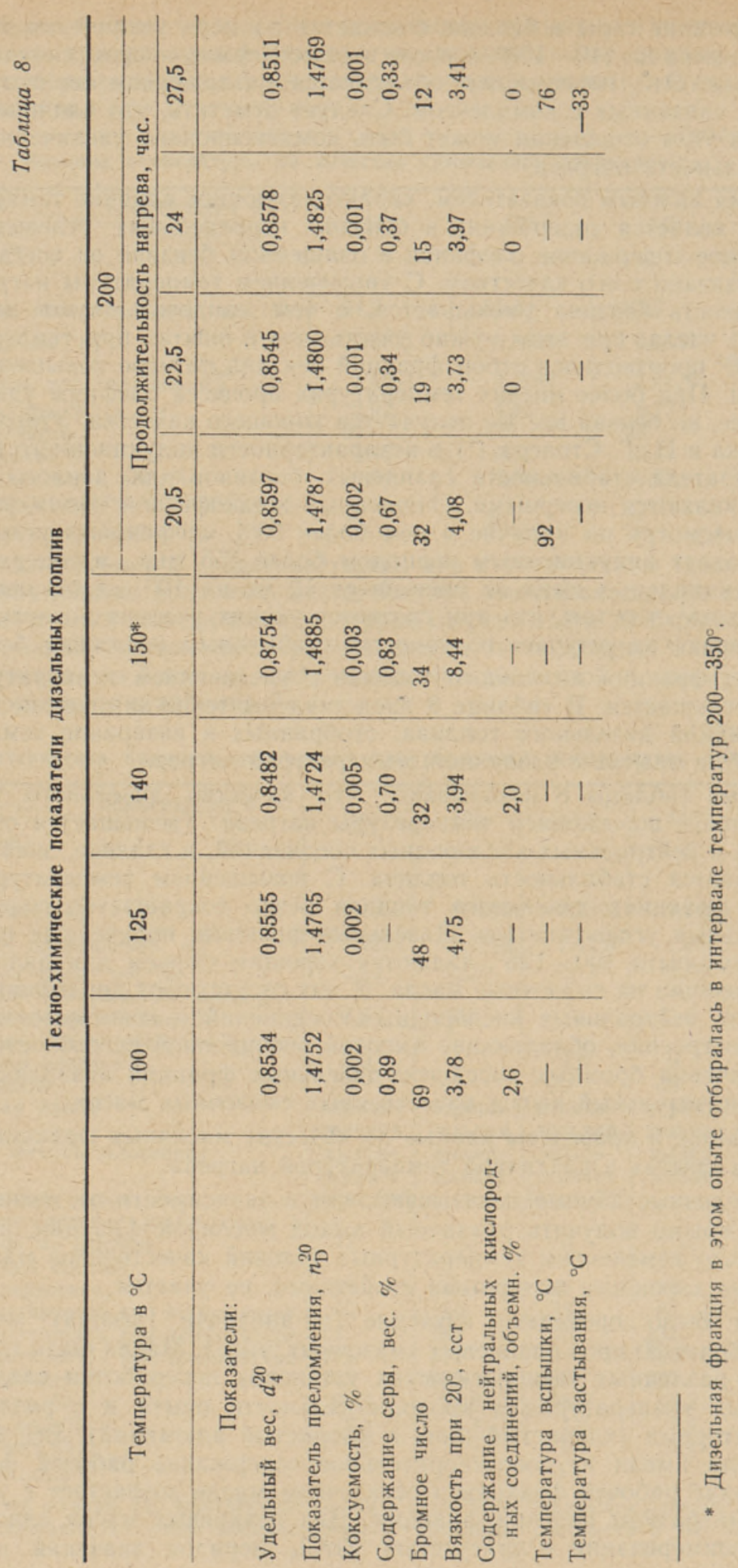


Качество сырых масляных фракций

\begin{tabular}{|c|c|c|c|c|c|}
\hline Температура в ${ }^{\circ} \mathrm{C}$ & 200 & 140 & \multicolumn{3}{|c|}{100} \\
\hline $\begin{array}{l}\text { Показатели: } \\
\text { Выход в \% на исходное сырье } \\
\text { Пределы кипения, }{ }^{\circ} \mathrm{C}\end{array}$ & $\begin{array}{l}29,4 \\
\text { остаток } \\
\text { выше } \\
320^{\circ}\end{array}$ & $\begin{array}{l}30,1 \\
\text { остаток } \\
\text { выше } \\
320^{\circ}\end{array}$ & $\begin{array}{l}16,5 \\
\text { остаток } \\
\text { выше } \\
320^{\circ}\end{array}$ & $\begin{array}{c}8,8 \\
320-390\end{array}$ & $\begin{array}{c}6,6 \\
390-480\end{array}$ \\
\hline Удельный вес, $d_{4}^{20}$ & 0,9566 & 0,9423 & 0,9520 & 0,9309 & 0,9705 \\
\hline Показатель преломлення, $n_{\mathrm{D}}^{20}$ & 1,5350 & 1,5275 & 1,5302 & 1,5190 & 1,5380 \\
\hline $\begin{array}{l}\text { Кинематическая вязкость в сст } \\
\text { при } 50^{\circ} \mathrm{C} \\
\text { при } 100^{\circ} \mathrm{C}\end{array}$ & $\begin{array}{l}88,0 \\
12,0\end{array}$ & $\begin{array}{l}86,0 \\
11,3\end{array}$ & $\begin{array}{r}58,1 \\
8,9\end{array}$ & $\begin{array}{c}17,6 \\
4,42\end{array}$ & $\begin{array}{l}17,5 \\
16,2\end{array}$ \\
\hline $\begin{array}{l}\text { Отношение кинематической вязкости } \\
\text { при } 50^{\circ} \mathrm{C} \text { к кинематической вязко- } \\
\text { сти при } 100^{\circ} \mathrm{C} \\
\text { Коксуемость, \% } \\
\text { Бромное число }\end{array}$ & $\begin{array}{l}6,7 \\
2,08 \\
43\end{array}$ & $\begin{array}{l}6,6 \\
1,18 \\
39\end{array}$ & $\begin{array}{l}6,5 \\
1,71 \\
69\end{array}$ & $\begin{array}{l}4,0 \\
0,02 \\
75\end{array}$ & $\begin{array}{l}10,8 \\
0,92 \\
66\end{array}$ \\
\hline $\begin{array}{l}\text { Моторные свойства при } 250^{\circ} \text { С и } 30 \text { мин. } \\
\text { а) испаряемость, вес. \% } \\
\text { б) рабочая фракция, вес. \% } \\
\text { в) лак, \% }\end{array}$ & $\overline{-}$ & $\begin{array}{c}86,0 \\
0 \\
14,0\end{array}$ & $\begin{array}{c}82,5 \\
0 \\
17,5\end{array}$ & $\overline{-}$ & $\begin{array}{c}88,0 \\
0 \\
12,0\end{array}$ \\
\hline
\end{tabular}

Таблица 10

Моторные свойства остаточных сланцевых смазочных масел при $250^{\circ}$ и 30 мин.

\begin{tabular}{c|c|c|c}
\hline Начало кипения, ${ }^{\circ} \mathrm{C}$ & $\begin{array}{c}\text { Моторная испаряемость, } \\
\text { вес. \% }\end{array}$ & $\begin{array}{c}\text { Рабочая фракция, } \\
\text { вес. \% }\end{array}$ & Лак, вес. \% \\
\hline & & & \\
320 & 86 & 0 & 14 \\
390 & 78 & 2 & 20 \\
480 & 8,5 & 68 & 23 \\
\hline
\end{tabular}

характеризующих их моторные свойства, может быть проиллюстрирован таблицей 10.

Эти и другие данные показывают, что при осуществлении глубокой вакуумной перегонки и при соответствующей очистке узких фракций методами, принятыми в нефтяной промышленности, можно получить различные марки индустриальных масел типа веретенных, машинных и автотракторных. Но это не полное решение задачи, которая заключается в том, чтобы, используя специфику химического состава сланцевой смолы, наиболее простыми путями синтезировать масла, не уступающие по качеству хорошим маркам нефтяных авиационных и автомобильных смазочных масел.

\section{Общая схема переработки легкой фракции сланцевой смолы}

Хроматографическое изучение химического состава сланцевых остаточных масел, полученных полимеризацией в присутствии хлористого цинка, показало, что они содержат $42 \%$ углеводородов, близких по показателям к парафиновому и нафтеновому рядам и обладающих повышенной термоокислительной стабильностью. Содержание этой фракции увеличивается с увеличением общего выхода масла на исходное сырье при увеличении продолжительности нагрева. 
Изучение влияния параметров процесса полимеризации, а также состава. и свойств получаемых продуктов позволило сделать предположение о целесообразной схеме переработки легкой фракции сланцевой смолы туннельных печей на бензин, дизельное топливо и смазочные масла. Основной принцип этой схемы заключается в осуществлении процесса полимеризации в две стадии. Вначале процесс полимеризации проводится до тақой глубины, которая обеспечивает стабилизацию бензина и удаление из широкой фракции легкого масла диолефинов, нестабильных моноолефинов и нейтральных кислородных соединений. Нестабильные составляющие удаляются частично в виде комплекса с катализатором и частично в виде остатка дестилляции с температурой кипения $370-380^{\circ}$. Остаток первой дестилляции после очистки отбеливающей глиной удовлетворяет требованиям, предъявляемым к цилиндровому маслу. Очищенная средняя фракция подвергается вторичной полимеризации и фракционированию на товарные продукты. Качественное смазочное масло получается во второй стадии полимеризации в виде остатка дестилляции с температурой кипения выше $320^{\circ}$. Для увеличения выхода масел во второй стадии процесса целесообразно добавление хлористого алюминия. В таблице 11 дается материальный баланс процесса переработки легкой фракции смолы туннельных печей при употреблении $10 \%$ хлористого цинка и $3 \%$ хлористого алюминия (на исходное сырье).

Расход катализатора в настоящее время не установлен. Установлено только, что хлористый цинк можно регенерировать с малыми потерями.

В таблице 12 приведены данные по качеству бензина.

Полученный бензин удовлетворяет требованиям, предъявляемым к автомобильному бензину А-70. Выше было показано, что содержание серы в бензине может быть снижено до $0,15 \%$. Однако это связано с уменьшением выходов. Следует также обратить внимание на то, что в исходной пробе отсутствовала часть бензиновых фракций, получаемых из печного и газового бензинов.

Техно-химические показатели дизельных топлив приведены в таблице 13.

Дизельное топливо, полученное по методу Института химии, бесцветное и стабильное. Содержание фактических смол в нем составляет 3,2 мг на 100 мл топлива. Оно является качественным топливом для быстроходных дизелей.

Данные о качестве авиационного смазочного масла приведены в таблице 14.

В связи с отсутствием в нашей лаборатории в настоящее время аппарата Пинкевича, коррозийность не определялась. Моторные свойства масла были определены при различных температурах в течение 30 мин. На рис. 1 приведены показатели моторных свойств смазочного масла, полученного в первой стадии полимеризации, авиационного масла второй стадии полимеризации, а также, для сравнения, автомобильного и авиационного нефтяных масел (автол-10 и МК-22) по данным К. К. Папока и Е. Г. Семенидо.

При $250^{\circ}$ и продолжительности нагрева 30 мин. в полученных нами маслах лакообразование отсутствует. Сланцевое авиационное масло характеризуется высоким содержанием рабочей фракции даже без сернокислотной или селективной очистки. Швейное масло удовлетворяет требованиям, предъявляемым ГОСТ 973-50.

Показатели цилиндрового масла представлены в таблице 15 .

Цилиндровое масло не удовлетворяет требованиям ГОСТ $6411-52$ в отношении температуры вспышки. Однако эти требования устарели. В настоящее время доказано, что для машин, работающих с перегревом 
Материальный баланс процесса переработки легкого масла туннельных печей

\begin{tabular}{c|r}
\hline Наименование продукта & Выход, вес. \% \\
\hline При ход & \\
Исходное сырье & 100,0 \\
Р а с ход & \\
Бензин & 29,6 \\
Дизельное топливо & 12,0 \\
Авиационное масло & 15,0 \\
Швейное масло & 12,5 \\
Цнлиндровое масло «6» & 9,0 \\
Мазут топочный & 18,0 \\
Потери & 3,9 \\
& \\
\hline Всего расход & 100,0
\end{tabular}

Таблица 12

Техно-химические показатели бензинов

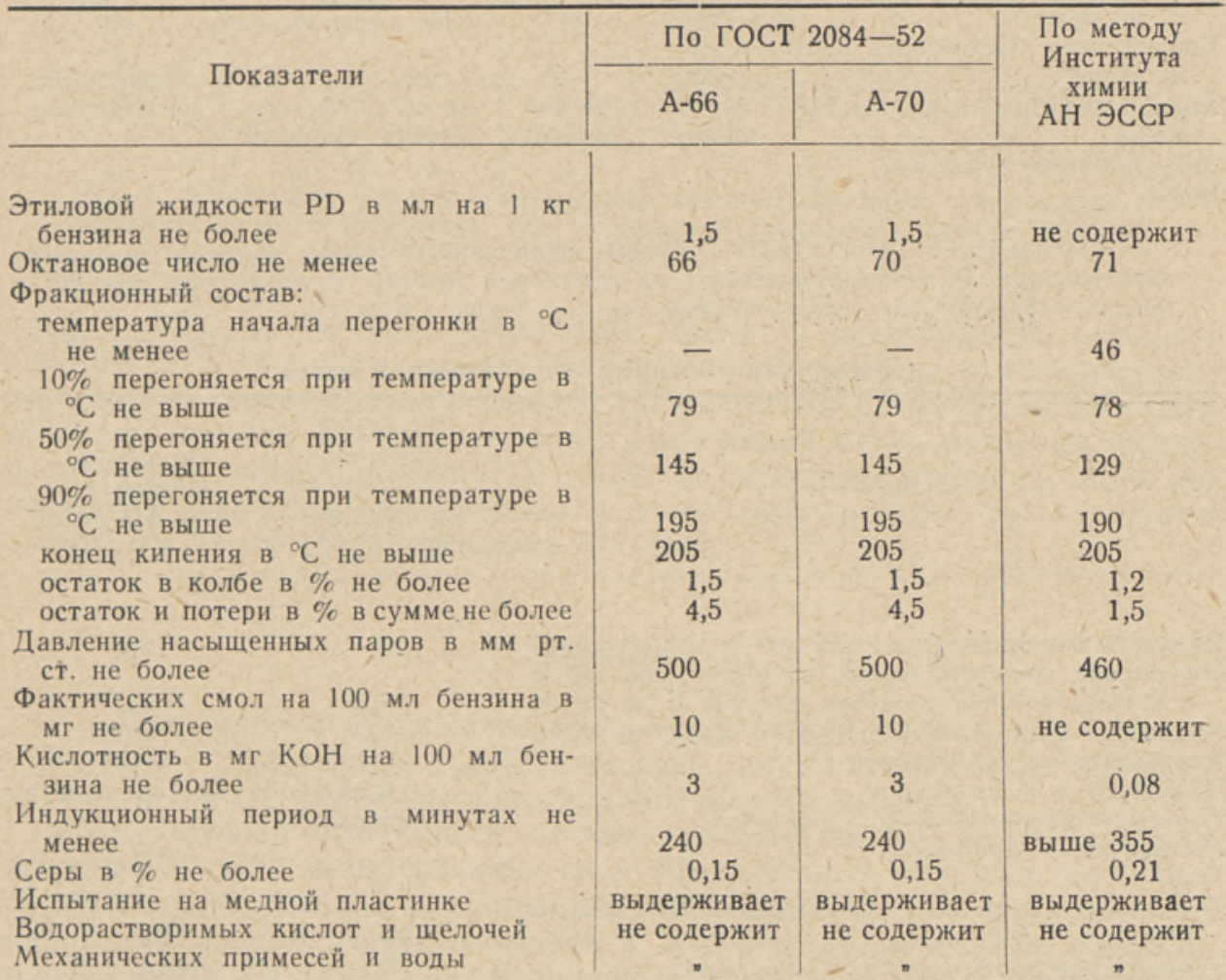

Пр и ме чан ие к ГОСТ 2084-52. «В бензинах А-66 и А-70, вырабатываемых из сернистых нефтей, при наличии установки для сернокислотной их очистки допускается содержание серы не более $0,4 \%$, а при отсутствии установки для сернокислотной очистки - не более $0,6 »\left({ }^{7}\right)$. 
Техно-химические показатели дизельного топлива

\begin{tabular}{|c|c|c|c|c|c|}
\hline \multirow{2}{*}{ Показатели } & \multicolumn{4}{|c|}{ По ГОСТ $4749-49$} & \multirow{2}{*}{$\begin{array}{l}\text { По методу } \\
\text { Института } \\
\text { химии } \\
\text { АН ЭССР }\end{array}$} \\
\hline & ДА & дз & ДЛ & ДС & \\
\hline Цетановое число не менее & 40 & 40 & 45 & 50 & 45 \\
\hline \multicolumn{6}{|l|}{$\begin{array}{l}\text { Фракционный состав: } \\
10 \% \text { перегоняется при темпе- }\end{array}$} \\
\hline ратуре в ${ }^{\circ} \mathrm{C}$ не ниже & 200 & 200 & - & - & 200 \\
\hline $\begin{array}{l}50 \% \text { перегоняется при темпе- } \\
\text { ратуре в }{ }^{\circ} \mathrm{C} \text { не выше }\end{array}$ & 255 & 275 & 290 & 280 & 226 \\
\hline $\begin{array}{l}90 \% \text { перегоняется при темпе- } \\
\text { ратуре в }{ }^{\circ} \mathrm{C} \text { не выше }\end{array}$ & 300 & 335 & 350 & & \\
\hline Вязкость при $20^{\circ}$, кинематиче- & & & & & 280 \\
\hline $\begin{array}{l}\text { ская, в сст } \\
\text { Коксуемость в \% не более }\end{array}$ & $\begin{array}{c}2,5-4,0 \\
0,05\end{array}$ & $\begin{array}{c}3,5-6.0 \\
-\end{array}$ & $3,5-8,0$ & - & $\begin{array}{l}2,44 \\
0\end{array}$ \\
\hline $\begin{array}{l}\text { Коксуемость 10\% остатка в } \\
\% \text { не более } \\
\text { Кнслотность в мг КОН на }\end{array}$ & - & 0,5 & $0, \dot{5}$ & 0,5 & 0,010 \\
\hline \multirow{3}{*}{$\begin{array}{l}\text { Кислотность в мг КОН на } \\
100 \text { мл топлива не более } \\
\text { Зольность в \% не более } \\
\text { Серы в \% не более } \\
\text { Пробу на медную пластинку }\end{array}$} & 5 & 5 & 5 & & 0,09 \\
\hline & $\begin{array}{l}0,01 \\
0,2\end{array}$ & $\begin{array}{l}0,02 \\
0,2\end{array}$ & $\begin{array}{l}0,02 \\
0,2\end{array}$ & $\begin{array}{l}0,02 \\
0,2\end{array}$ & $\begin{array}{c}\text { отсутствует } \\
0,55\end{array}$ \\
\hline & $\begin{array}{l}\text { выдер- } \\
\text { живает }\end{array}$ & $\begin{array}{l}\text { выдер- } \\
\text { живает }\end{array}$ & $\begin{array}{l}\text { выдер- } \\
\text { живает }\end{array}$ & $\begin{array}{l}\text { выдер- } \\
\text { живает }\end{array}$ & выдерживает \\
\hline \multicolumn{6}{|l|}{$\begin{array}{l}\text { Температура вспышки (опреде- } \\
\text { ляемая в закрытом тигле) в } \\
{ }^{\circ} \mathrm{C} \text { не ниже }\end{array}$} \\
\hline $\begin{array}{l}\text { Tемпература застывания в }{ }^{\circ} \mathrm{C} \\
\text { не выше }\end{array}$ & -60 & -45 & -10 & -15 & ниже -33 \\
\hline Водорастворимых кислот и ще- & $\begin{array}{l}\text { не со- } \\
\text { держит }\end{array}$ & $\begin{array}{l}\text { не со- } \\
\text { держит }\end{array}$ & $\begin{array}{l}\text { не со- } \\
\text { держит }\end{array}$ & $\begin{array}{l}\text { не со- } \\
\text { держит }\end{array}$ & не содержит \\
\hline $\begin{array}{l}\text { Механических примесей } \\
\text { Воды }\end{array}$ & . & ” & $n$ & . & 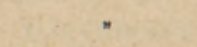 \\
\hline Воды & $"$ & $"$ & " & $"$ & " \\
\hline
\end{tabular}

При меч ани е к ГОСТ 4749-49. «Допускается сдача топлива дизельного автотрактора Л, вырабатываемого из сернистых нефтей, с вязкостью при $20^{\circ}$ в пределах $3,0-8,5$ сст с содержанием серы не более $1,0 \%\left({ }^{7}\right)$.

Таблица 14

Показатели авиационного смазочного масла

\begin{tabular}{|c|c|c|}
\hline \multirow{2}{*}{ Показатели } & $\begin{array}{r}\text { По ГОСТ } \\
1013-40\end{array}$ & \multirow{2}{*}{$\begin{array}{c}\text { По методу } \\
\text { Института } \\
\text { хими АН ӘССР }\end{array}$} \\
\hline & $\begin{array}{l}\text { Авиационное } \\
\text { масло } \mathrm{MC}-14\end{array}$ & \\
\hline Вязкость кинематическая при $100^{\circ}$ с сст не менее & 14 & 15,4 \\
\hline $\begin{array}{l}\text { Отношение кинематической вязкости при } 50^{\circ} \mathrm{C} \\
\text { к кинематической вязкости при } 100^{\circ} \mathrm{C} \text { не более }\end{array}$ & 655 & \\
\hline $\begin{array}{l}\text { Кислотное число в мг КОН на } 1 \text { г масла не более } \\
\text { Коксуемость в \% не более }\end{array}$ & $\begin{array}{l}0,25 \\
0,45\end{array}$ & 0,082 \\
\hline Зольность в \% не более & 0,003 & не содержит \\
\hline Водорастворимых кислот и щелочей & не содержит & $n$ \\
\hline $\begin{array}{l}\text { Механических примесей } \\
\text { Воды }\end{array}$ & $\eta$ & $"$ \\
\hline $\begin{array}{l}\text { Температура вспышки (определяемая в открытом } \\
\text { тигле) в }{ }^{\circ} \mathrm{C} \text { не ниже }\end{array}$ & 220 & 220 \\
\hline Температура застывания в ${ }^{\circ} \mathrm{C}$ не выше & -30 & ниже -28 \\
\hline $\begin{array}{l}\text { Цвет смеси } 15 \text { частей масла и } 85 \text { частей бесцвет- } \\
\text { ного лигроина по Дюбоксу в мм не менее }\end{array}$ & 16 & более 16 \\
\hline Плотность $d_{4}^{20}$ не выше & 0,890 & 0,9194 \\
\hline $\begin{array}{l}\text { Термоокислительная стабильность по методу } \\
\text { Папока при } 250^{\circ} \text { в минутах }\end{array}$ & & 25 \\
\hline
\end{tabular}




\begin{tabular}{|c|c|c|}
\hline Показатели & $\begin{array}{l}\text { По ГОСТ } \\
6411-52\end{array}$ & $\begin{array}{c}\text { По методу } \\
\text { Института } \\
\text { химии АН ЭССР }\end{array}$ \\
\hline $\begin{array}{l}\text { Вязкость кинематическая в сст при } 100^{\circ} \mathrm{C} \\
\text { Коксуемость, \% } \\
\text { Зольность, \% } \\
\text { Температура вспышки (определяемая в открытом } \\
\text { тигле), }{ }^{\circ} \mathrm{C} \\
\text { Воды, \% } \\
\text { Механических примесей, \% } \\
\text { Температура застывания, }{ }^{\circ} \mathrm{C} \\
\text { Водорастворимых кислоты и щелочи }\end{array}$ & $\begin{array}{c}32-44 \\
3,0 \\
0,015 \\
300 \\
0,05 \\
\text { отсутствие } \\
17 \\
\text { отсутствие }\end{array}$ & $\begin{array}{c}34,6 \\
3,14 \\
\text { отсутствует } \\
\\
240 \\
\text { не содержит } \\
\quad 3 \\
2 \\
\text { не содержит }\end{array}$ \\
\hline
\end{tabular}

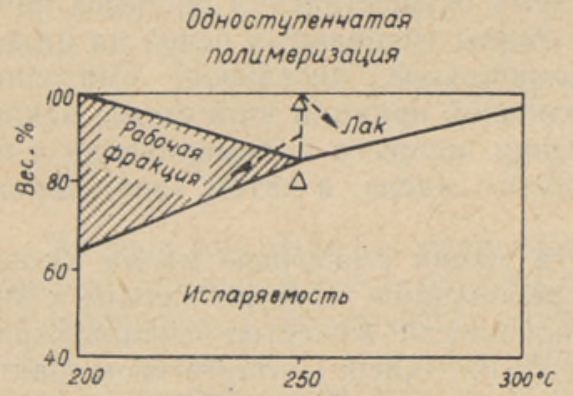

$\triangle A B \operatorname{mon} 10$

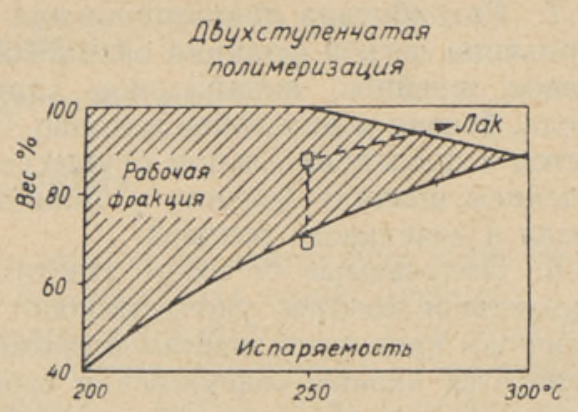

口 Macro MK 22

Рис. 1. Изменение тонкого слоя масла на металлической поверхности в зависимости от температуры при постоянной продолжительности нагрева (30 мин.).

пара до $330^{\circ}$, могут быть применены масла с температурой вспышки $180-200^{\circ}\left({ }^{5}\right)$. Топочный мазут не содержит вовсе золы и механических примесей и может служить ценной добавкой для разбавления тяжелых топочных мазутов. По предлагаемой схеме общий выход моторных топлив и смазочных масел достигает $75-80 \%$. В настоящее время из этого же исходного сырья в промышленных условиях производится только бензин с выходом на исходную фракцию $40-45 \%$.

\section{Выводы}

1. Химизм и кинетика процесса полимеризации компонентов сланцевой смолы в присутствии солей галоидных металлов зависят от природы катализатора, температуры и продолжительности нагрева.

2. Специфика химического состава сланцевой смолы дает возможность провести процесс полимеризации ее в присутствии хлористого цинка последовательно, вначале диеновых углеводородов и кислородных соединений, затем разветвленных олефинов и, наконец, моноолефинов нормального строения. Это позволяет параллельно с очисткой дестиллятных фракций и получением моторных топлив синтезировать смазочные масла удовлетворительного качества.

3. С увеличением продолжительности процесса все большее количество соединений вступает в реакцию полимеризации. При этом улучшается 
качество бензина за счет меньшего выхода его, увеличивается выход фракции смазочного масла и уменьшаются его коксуемость и вязкость.

4. Изменение температуры процесса влияет на направление химических реакций. С увеличением температуры все большее значение приобретает циклизация углеводородов, которая приводит к образованию нестабильных при термоокислении конденсированных систем.

5. Степень разложения образующегося в процессе комплекса кислородных и непредельных соединений с хлористым цинком при повышении температуры процесса увеличивается. При этом комплекс теряет свою подвижность, и усложняется распад его при регенерации.

Ведение процесса при температуре выше $150^{\circ}$ приводит к образованию -твердого при комнатной температуре, не разлагаемого водой соединения.

6. Выходы бензина, дизельного топлива и смазочных масел зависят от температуры нагрева. Изменение температурных условий не приводит к получению качественного масла, обладающего хорошими моторными свойствами.

7. Разработана принципиальная схема осуществления процесса полимеризации легкой фракции сланцевой смолы туннельных печей на цилиндровое, швейное, авиационное (автомобильное, дизельное) смазочные масла, бензин и дизельное топливо. Основной принцип этой схемы заключается в последовательном осуществлении процесса полимеризации с получением вначале бензина и цилиндрового масла, а затем авиационного масла и дизельного топлива.

8. Получаемые по схеме Института химии смазочные масла, бензин и дизельное топливо удовлетворяют требованиям, предъявляемым к аналогичным продуктам нефтяной промышленности. Качество бензина характеризуется низким содержанием серы $(0,15-0,25 \%)$, отсутствием фактических смол и высоким индукционным периодом (более 355 мин). Авиационное смазочное масло обладает высокой термоокислительной стабильностью и низкой коксуемостью. Дизельное топливо бесцветное и стабильное; цетановое число его не менее 43.

\section{Ннститут химии \\ Академии наук Эстонской ССР \\ Поступила в редакцию \\ 29 XII 1955}

\section{ЛИТЕРАТУРА}

1. А. М. Кулиев, Пути улучшения качеств нефтяных смазочных масел, Азнефтеиздат, Баку, 1954.

2. А. Т. К ылль, С. И. Ф а й нгольд, М. Ю. К ор в, Жидкофазная стабилизация сланцевого бензина. Сборник \&Горючие сланцы. Химия и технология», вып. 2 , Таллин, 1956.

3. Моторные топлива, масла и жидкости, том II. Под редакцией К. К. Папока и Е. Г. Семенидо. Гостоптехиздат, Москва-Ленинград, 1953.

4. С. С. С е м е нов, Б. Е. Г у ре в и ч, Полимеризация олефинов сланцевой смолы на масла в присутствии хлористого алюминия, Труды ВНИИПС, вып. 2, Гостоптехиздат, 1954.

5. И. Г. С толе р, И. А. У ск, Изыскания способов улучшения качества сланцевого бензина. Сборник «Горючие сланцы. Химия и технология», вып. 2, Таллин, 1956.

6. Технические нормы на нефтепродукты. Издание четырнадцатое, Гостоптехиздат, Москва-Ленинград, 1952.

7. Технические нормы на нефтепродукты. Издание пятнадцатое, переработанное и дополненное. Под редакцией Н. Г. Пучкова. Гостоптехиздат, Москва, 1955.

8. Ч. Т о м а с, Безводный хлористый алюминий в органической химии, ИЛ, Москва, 1949.

9. А. В. Топи иев, М. В. Курашев и Б. А. Кренцель, Синтез изопропилбензола по реакции алкилирования с помощью $\mathrm{AlCl}_{2} \mathrm{HSO}_{4}$, Журнал прикладной химин, т. XXVIII, № 9, 1955 , стр. 976.

10. С. И. Ф й нгольд, М. Ю. К о в, Парофазная очистка сланцевого бензина, Сборник «Горючие сланцы. Химия и технология», вып. 2, Таллин, 1956. 